\title{
Researching Graphic Novels and Their Teenage Readers Clare Snowball
}

Clare.snowball@postgrad.curtin.edu.au

\begin{abstract}
Graphic novels are becoming more prevalent and popular among teenagers and are thus being collected by public and school libraries. This situation contributed to the doctoral researcher's desire to investigate graphic novel collections in public libraries in Australia, what teenagers think of graphic novels and whether they read them. This paper discusses the three research methods of the project. One method, the survey of public libraries, has been completed, and some preliminary results of the survey are examined.
\end{abstract}

\section{Researching Graphic Novels}

It has been suggested to "choose an emerging trend" when selecting a research topic (Macauley, 2006, p. 23). Even though comics, and more recently graphic novels, have been around for decades (Gravett, 2005), the current prevalence of graphic novels in the literature and library collections contributes to their status as an emerging trend.

A graphic novel is "any trade paperback or hardcover book consisting of work in comic-book form” (Raiteri, 2002, p. 148). Graphic novels include book-length stories, collections of stories, and, to complicate matters, works of non-fiction. They do not include collections of comic strips such as Garfield or Peanuts. Graphic novels are a format and as such include many different genres (Kan, 2003, p. 15). They are written for all different age groups but are commonly collected by public libraries as reading material for teenagers.

The objective of this research project is to investigate whether the inclusion of graphic novels in public library collections encourages teenagers to use public libraries as a source of recreational reading material and thus to read more.

\section{Significance of the Research}

Collection development in libraries should be aimed at identified needs, which can be determined through needs assessment of particular user populations (Evans \& Saponaro, 2005, p. 20). Teenagers often show a declining interest in reading (Baker, Dreher, \& Guthrie, 2000) and are thus not regular users of libraries. Because public libraries are aimed at the whole community rather than just the current or most active library users (Chartered Institute of Library and Information Professionals, 2005), investigation of groups such as teenagers is useful in order to ascertain how they can be encouraged to use library collections.

"When it comes to libraries, adults generally talk about children but rarely talk to them" (Druin, 2005, p. 21). One part of this research will investigate the needs of teenagers as a potential user group through talking to them and discovering what they read, particularly whether they read graphic novels.

Much of the literature indicates that graphic novels encourage teenagers to read (Crawford, 2003; Goldsmith, 2005; Gorman, 2003; Krashen, 2004; Lyga \& Lyga, 2004; Miller, 2005; Sullivan, 2002; Versaci, 2001). Although this is mainly anecdotal 
evidence from librarians and teachers, the current research project seeks to provide evidence gathered from teenagers themselves.

Graphic novels are being used in secondary and tertiary level classrooms (Frey \& Fisher, 2004; Mahoney, 2006; O’English, Matthews, \& Lindsay, 2006) and are thus being collected by school and academic libraries. The development of "students' analytical and critical reading of visual texts” (Schwartz \& Rubinstein-Avila, 2006, p. 47) is increasingly important in today’s curricula (Albright \& Walsh, 2003).

Since this research project is focused on graphic novels as a recreational reading material, it is hoped the results will "have significant consequences for practical decisions" (Buckland, 2003, p. 677) in public libraries. Librarians will be able to use the results of the research to inform their decisions about young adult collections.

\section{Research Methods}

The current research employs a number of research methods and different population groups to allow triangulation (Powell \& Connaway, 2004, p. 124). This strategy improves the quality of the research through increased reliability and validity (Creswell, 2002, p. 565; Gorman \& Clayton, 2005, p. 13, 56-60). Triangulation "clarifies meaning by identifying different ways the phenomenon is seen" (Stake, 2000, p. 444), in this case, from the point of view of teenagers and librarians.

A postal survey of public libraries in Australia was conducted to determine whether public libraries have graphic novel collections and how these collections are selected, acquired, catalogued, housed, and promoted. Focus groups with teenagers were conducted to uncover what teenagers think of graphic novels and whether they read them. Public librarians who have graphic novel collections in their library will be interviewed to determine their thoughts on their collections and the format in general.

\section{Interviews with Public Librarians}

Interviews will be held with selected Western Australian Young Peoples' Services (YPS) librarians. The following issues will be investigated:

- The attitudes of YPS librarians to the place of graphic novel collections in public libraries.

- How current theories of collection development may affect the ability of public libraries to collect graphic novels.

- Whether graphic novels encourage teenagers’ recreational reading.

The aim of the interviews is "to document expert opinions ... [and provide] a rich, detailed, holistic picture of people's experience and how they interpret it" (Doyle, 2004, np). It is hoped the interviews will be rewarding for both the researcher and the librarians interviewed. "Talking ... about things that matter to the interviewee and doing so in a way that provides appropriate feedback often provides subjects with an intangible yet intrinsic reward" (Berg, 2004, p. 92). Interviews enable the exploration of causation; therefore, the reasons why things happen the way they do will be discovered (Gorman \& Clayton, 2005, p. 125). Very general questions will be asked that "encourage participants to 'open up' ... and give their perspectives with as little influence from the researcher as possible” (Bouma \& Ling, 2004, p. 177). 
Librarians for the interviews will be selected from the researcher's network of contacts and knowledge of libraries in Perth, Western Australia (WA) that have graphic novel collections. Interviews will be held with ten librarians. After recent contact with teacher librarians in high schools, the inclusion of some teacher librarians who have graphic novel collections is being considered.

\section{Focus Groups with Teenagers}

Focus groups were held with teenagers to garner their opinions on reading, particularly reading of graphic novels. Some of the issues investigated were:

- Teenagers' attitudes toward libraries and their use of libraries.

- What teenagers think of graphic novels as a reading material.

- Whether teenagers would use libraries if graphic novels were included in library collections.

There has been much research in which teenagers' views were gathered through focus groups. A focus group is "an informal discussion among selected individuals about specific topics” (Beck et al. cited in Wilkinson, 1998, p. 182).

Wood-Charlesworth and Rodwell found the focus group method to be "highly feasible” in working with children (1997, p. 1205). In another study, a library evaluation, after determining that surveys were not appropriate in soliciting children's and teenagers' views on a library service, focus groups were planned in order to discover their opinions (Haynes, 2004, p. 296). Berg believes the method works well with teenagers (2004, p. 123) and Powell and Connaway note its usefulness with hardto-reach groups such as teenagers (2004, p. 154). Group members are "on a more even footing” with each other and the researcher (Berg, 2004, p. 127). Vaillancourt mentions the effectiveness of focus groups involving teenagers in public libraries (2000, p. 16), and Wilkinson notes their success in classrooms (2004, p. 178). Campher et al. used focus groups of eighth graders in their school and found them to "be a rich source of information” (1996, p. 7). In a UK study of teenagers' library use and reading habits, focus groups were held at schools. "The focus groups were most useful for gaining the collective opinion of teenagers" (Dodds \& Cheesman, 2003, p. 15). Page (2005) used focus groups with teenagers in Australian schools and found them to be most beneficial.

Finding teenagers to take part in research can prove problematic. In this instance, they cannot be accessed through a public library because reluctant readers are being targeted and they may have no connection to a library. High schools, which are part of the researcher's network of contacts, have provided the solution to this problem. This method of accessing teenagers' participation for a research project has proven successful in other studies (Loubeau, 2000, p. 112; Shenton \& Dixon, 2004, p. 179; Sieber, 1992, p. 121).

Wood-Charlesworth and Rodwell recommend groups of between six and eight children (1997, p. 1210) whereas Page (2005) found five teenagers to a group worked well. The similarity between this project and Page's research led to the choice of groups of five teenagers. Walter recommended four sessions with teenagers be held (1995, p. 35). This had originally been planned for the project but with each group having ten participants. Seven sessions will now be held because of the decrease in each group's size. 
Wood-Charlesworth and Rodwell found that age is a factor in determining group structure (1997, p.1210). Different age groups can have very different opinions; therefore, focus groups had homogenous age ranges (Krueger \& Casey, 2000, p. 178).

The intent of focus groups is to "find out the range of feelings and opinions on the topic” (Krueger \& Casey, 2000, p. 201). That responses will be in the teenagers' own words is important (Walter, 1995, p. 35; Wood-Charlesworth \& Rodwell, 1997, p. 1208), and the flexibility of focus groups means unexpected issues may emerge during the discussion (Widdows, Hensler, \& Wyncott, 1991, p. 356; Wilkinson, 2004, p. 182).

Interactions among group members stimulate discussion and group members react to comments made by each other (Berg, 2004, p. 124; Creswell, 2002, p. 206; Walter, 1995, p. 34; Williamson et al., 2006, p. 59). This makes a focus group particularly useful for garnering teenagers' views because they can frequently be unwilling to participate in activities. The focus group provides a less threatening environment for "individuals who are unwilling to talk without peer support" (Gorman \& Clayton, 2005, p. 49) and for those "who may be uncomfortable with individual interviews but happy to talk to others" (Plaut et al. in Wilkinson, 2004, p. 181). In discussing focus groups with teenagers, Walter has said, "group dynamics . . . can produce an exciting synergy in the group as people are reminded of things they want to say by the comments of others. ... The results can be unusually rich” (1995, p. 34).

As the facilitator, the researcher led the groups with guidance from a written list of discussion points (Gorman \& Clayton, 2005, p. 196). Discussions were tape recorded and, at a couple of points, students were asked to brainstorm their thoughts on butcher's paper. As a start to the discussion, the students were told they are the experts in the dialogue and they are informing the "ignorant adult researcher" (Thomson, 1987, p. 231).

Problems such as more than one person talking at once or one person dominating the discussion are possible when conducting focus groups. Ground rules established at the beginning of the session combated these difficulties. Problems with the methodology can be minimized by using other research methods and more than one population group (Gorman \& Clayton, 2005, p. 149), both of which are being undertaken.

Although it would be useful to talk to teenagers from rural and remote areas and other states in Australia, due to cost and time constraints this is, unfortunately, not possible in this project. This will be an important consideration for further research.

\section{Sampling for the Focus Groups}

Non-probability sampling often occurs in social sciences research because it may not be possible to select large-scale samples, for example, with hard-to-research populations (Berg, 2004, p. 34). This is the case when studying teenagers. Although a random sample could be selected, ensuring the majority of teenagers in the sample agreed to the research (and their parents gave consent) would be difficult and would thus negate the random selection.

Purposive sampling was used to select the schools (Creswell, 2002, p. 194). From work as a public librarian, the researcher's contacts with high schools in Perth, WA provided access to schools, and those that agreed to take part were included. 
Most high schools have more than one class for each school year. The Australian Council for Educational Research (ACER) has recommended using participants from the same school class because these children "tend to resemble each other more than they resemble" those from other classes in a school (Bunbury, 1995, p. 35). Therefore, only one class from each school was selected to take part. From a year nine or ten English class at each school, five students who returned the parental permission slip were selected at random (Krueger \& Casey, 2000, p. 173).

A number of studies of young people have used purposive sampling (Agosto \& Hughes-Hassell, 2006; Hale, 1994; Love \& Hamston, 2003). Love and Hamston examined "one group of teenage boys in one specifically situated context in Australia" (2003, p. 162); thus their sample was not representative. Agosto and Hughes-Hassell sought to "create a very detailed description of a smaller pool of participants than quantitative research typically employs" (2006, p. 1400). It is hoped the same will be achieved through the focus groups in the current project. As the students who took part in the focus groups are not necessarily a representative sample, generalization to all teenagers is not possible (Agosto \& Hughes-Hassell, 2006; Creswell, 2002). The results of the focus groups will, however, allow an insight into what some teenagers think of reading and of graphic novels and suggest directions for further research.

Focus group sessions were conducted during October and November 2006.

\section{Survey of Public Libraries}

A postal survey of public libraries in Australia was completed in January and February 2006. Preliminary analysis has been undertaken to determine whether public libraries have graphic novel collections and how these collections are selected, acquired, catalogued, housed, and promoted.

\section{Dissemination of the Survey}

The data collection method of a postal survey was chosen because there were a large number of respondents (167) and the whole of Australia was to be covered (Creswell, 2002, p. 403).

Sending the questionnaire by e-mail was considered, but a survey "distributed electronically will reach only those who have access to and are comfortable using email” (Powell \& Connaway, 2004, p. 126). Some respondents in small rural or remote libraries may not have had adequate or reliable Internet connections and thus electronic distribution may have caused problems. In addition, the literature suggested traditional mail-based surveys received a better response (Hayslett \& Wildemuth, 2004; Powell \& Connaway, 2004; Schonlau, Fricker, \& Elliott, 2002), so this method of dissemination and return was used.

\section{Sampling for the Survey}

The Directory of Australian Public Libraries (Bundy \& Bundy, 2006) is published every three years and lists public libraries in Australia. At the time of compiling the sample, the most recent edition was the sixth, published in 2003. An online listing of public libraries was considered more up to date.

The website Australian Libraries Gateway lists public libraries in Australia (National Library of Australia, 2005). The site listed 1527 public libraries, but the latest data 
from the Australian Bureau of Statistics states the number of public libraries as 1716 (ABS, 2005). A combination of lists of public libraries from State Libraries and public library authorities of the Territories, Australian Libraries Gateway, and local government websites provided the final population listing.

Mobile Libraries, Railway Express Services, Library Depots, and very small branches that are open only a couple of hours a week (an example being Nangwarry Branch Library, South Australia) were not included in the sample. These collections are often very small (between 2000 and 4000 items) and may be rotated from their main library (Hawke \& Jenks, 2005). This last exclusion, of Library Depots and very small branches, was not always easy to discern and so some may have inadvertently been included within the sample.

\section{Problems with the Sample}

A random sample was selected from the population using random numbers, but some problems occurred.

Each local government council provides public libraries for their area. Some local governments have only one library, but many have more than one. These libraries are a part of the council's library system. Only one library from any library system was chosen because it was considered that the libraries would be similar within a system. It was subsequently discovered this was not always the case, and this led to the sample not being as representative as planned.

After talking with numerous librarians and library officers through telephone reminders, the differences between library systems were better appreciated. Some had centralised selection of materials for all branches; some had only centralised processing and cataloguing; and others had total autonomy in their selection, processing, and cataloguing of materials. Some systems had graphic novel collections at all branches, and some had a collection at only one branch.

Four of the respondents said they were a smaller branch and thus had no graphic novels, but another library in the system did have a graphic novel collection. The questionnaire had been completed for that library, which had not been initially included in the sample. One of the smaller branches said there were four libraries in their system, and this branch was the only one that did not have a graphic novel collection.

\section{Reminders}

Reminders were very important as only $30.54 \%$ of the questionnaires were returned prior to the first reminder. Mangione (1998) and Dillman (2000) map out a schedule of reminders to improve response rates. Their schedule suggestions were combined, and two reminders were sent by mail and a third reminder by telephone, with two weeks between each reminder. The first postal reminder was postcard size; and the second included a reworded cover letter, a replacement questionnaire, and reply-paid envelope.

Every questionnaire had an individual number corresponding to the list of libraries in the sample. Each library was removed from the list as its survey was returned and the number removed from the questionnaire. This ensured that reminders would be sent only to those libraries that had not yet returned the questionnaire.

$\operatorname{Pg} 6$ 


\section{Telephone Reminder}

Telephone reminders were essential in increasing the response rate. The differences in individual libraries and local councils in receiving mail caused problems that could be resolved only by telephoning the libraries.

Some respondents were encouraged to complete the survey when they had previously disregarded it, and some were willing to answer the questions over the telephone.

A few respondents said they were too busy to complete it, which was helpful to know. Another respondent said she had been busy and had not completed it. After thanking her for considering it, she continued by saying she did want to help with research and asked to be sent another copy. This was a very pleasant outcome.

Having a name within the library to personally address a letter to is useful. Some respondents had not received the questionnaire; and after a telephone call, there was a name to personally address the letter to. One respondent said that if a letter is not marked "Personal" it will be opened by the Records Department and "could end up anywhere.” In this case, the librarian had never seen any of the three mailings.

Some libraries had different positions responsible for acquisitions and junior collections, so more than one person had to complete different parts of the questionnaire. A couple of these respondents had filled in only the parts they could and had not completed the rest. The telephone reminder provided encouragement for them to send it on to their colleague who could complete the questionnaire and return it. This problem could only be resolved by a conversation; thus the telephone reminder was invaluable.

One library in rural Queensland said they were a small library ( 4000 items) and the State Library of Queensland (SLQ) selected their stock, so the library officer could not answer the questionnaire. After telephoning the library it was ascertained that the library did have a collection for teenagers with some graphic novels that were wellused. The library could answer questions about how the graphic novels were shelved and used, but SLQ had to be contacted to answer questions about selection and cataloguing.

The time and the cost involved in telephoning libraries that had not returned questionnaires were validated in terms of the increase in responses.

\section{Return Rate}

The return rate was improved by $46.71 \%$, from $30.54 \%$ to $77.25 \%$, through the schedule of reminders. Table 1 and Figure 1 show the number of responses received after each reminder. 
Table 1: Response after each reminder

\begin{tabular}{l|r|r|r|r|r|r|r|r|r|r} 
& ACT & NSW & NT & QLD & SA & TAS & VIC & WA & $\begin{array}{r}\text { Total } \\
\text { Number }\end{array}$ & $\begin{array}{l}\text { Percentage } \\
\text { returned }\end{array}$ \\
\hline Survey posted & 4 & 7 & 3 & 10 & 7 & & 8 & 12 & 51 & $30.54 \%$ \\
\hline First Reminder & & 7 & 2 & 1 & 2 & & 2 & 4 & 18 & $10.78 \%$ \\
\hline $\begin{array}{l}\text { Second } \\
\text { Reminder }\end{array}$ & & 3 & 2 & 2 & 7 & 2 & 3 & 4 & 23 & $13.77 \%$ \\
\hline $\begin{array}{l}\text { Telephone } \\
\text { reminder }\end{array}$ & & 7 & & 8 & 7 & & 3 & 1 & 26 & $15.57 \%$ \\
\hline $\begin{array}{l}\text { Subsequent } \\
\text { mailing }\end{array}$ & & 2 & & 2 & & 6 & 1 & & 11 & $6.59 \%$ \\
\hline Total & 4 & 26 & 8 & 24 & 23 & 8 & 19 & 21 & 133 & $77.25 \%$
\end{tabular}

Where: $A C T=$ Australian Capital Territory, NSW $=$ New South Wales, NT $=$ Northern Territory, QId $=$ Queensland, SA $=$ South Australia, TAS $=$ Tasmania, Vic $=$ Victoria, WA $=$ Western Australia.

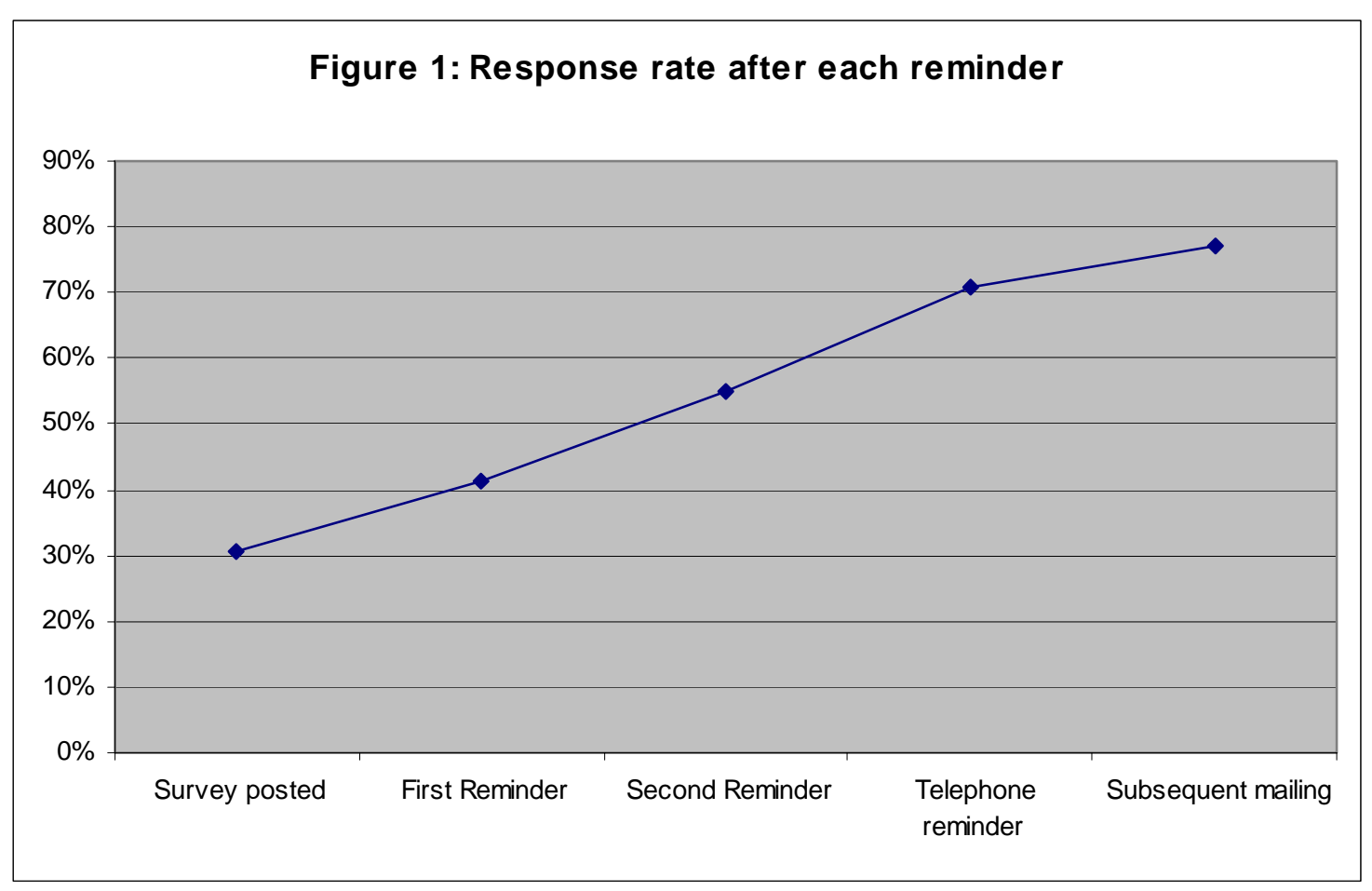

The fact that public library staff were surveyed may have contributed to the high response rate, this group being particularly interested in the results of the survey.

\section{Thanking the Survey Respondents}

Since respondents were not offered anything in return for completing the questionnaire, it was important to thank them for their participation. An e-mail or traditional mail postcard was sent to all respondents as a thank you. (Some respondents had supplied their e-mail address during the telephone interviews and fifteen thank-you e-mails were sent.) The thank-you message included a link to the research project website (http://alia.org.au/ csnow/), where information about graphic novels and the research project is available. 


\section{Preliminary Survey Results}

Due to problems encountered with the sample, caution should be exercised in generalizing the results to all public libraries in Australia.

One hundred and sixty seven public libraries in Australia were surveyed, with one hundred and twenty nine questionnaires being returned. Of those returning questionnaires, 75.97\% ( $\mathrm{n}=98)$ had graphic novel collections, and 24.03\% $(\mathrm{n}=31)$ did not.

The reasons for a library not having graphic novels are shown in Figure 2. They included the following: a graphic novel collection had not been considered $64.52 \%$ $(n=20)$, the library was too small $9.68 \%(n=3)$, there was no budget for a graphic novel collection $16.13 \%(n=5)$, there were no graphic novel users $35.48 \%(n=11)$, or there was a collection at another branch in the system $9.68 \%(n=3)$. Respondents could mark more than one reason, so the percentages do not total 100\%.

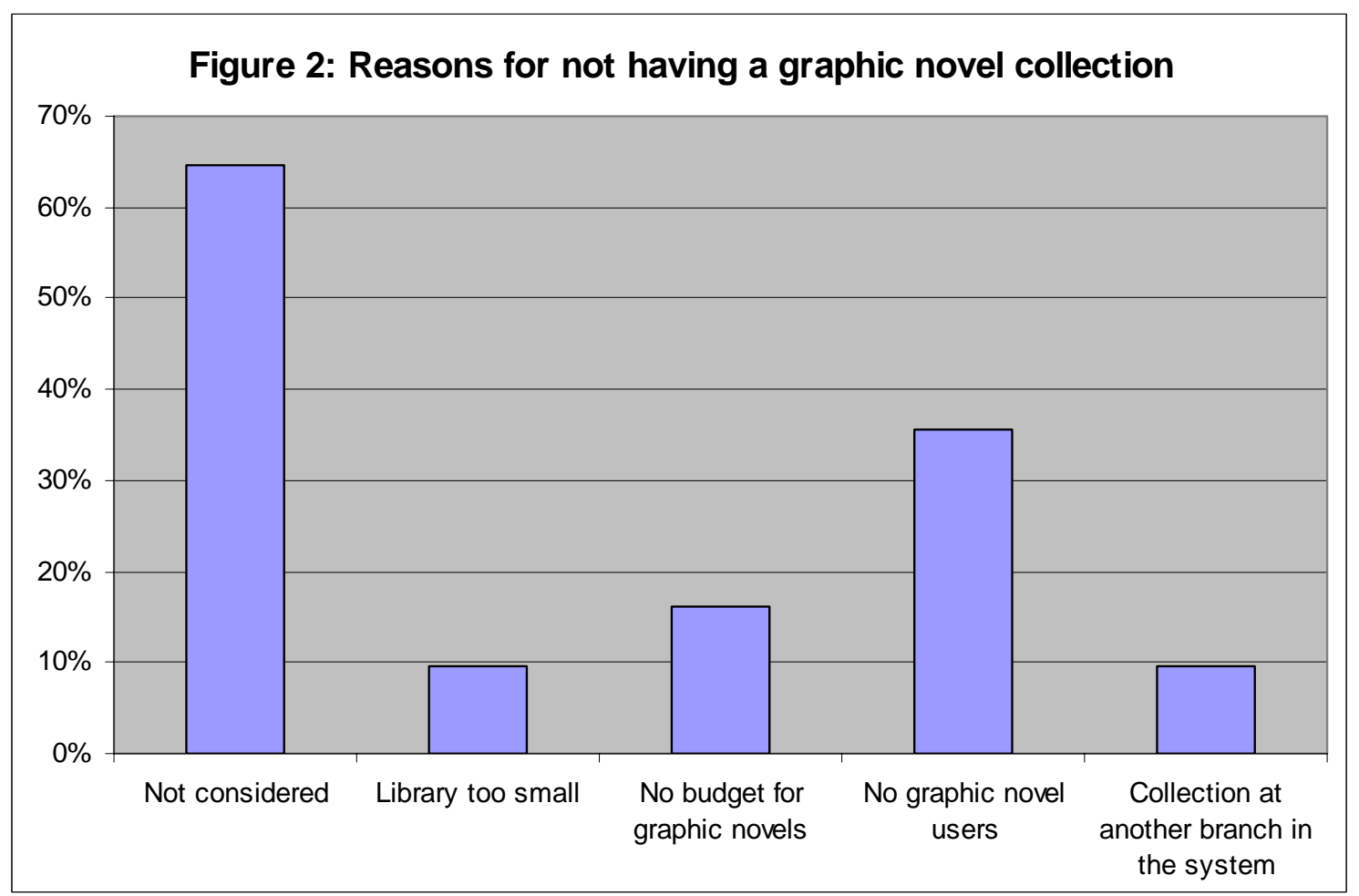

One rural NSW librarian said of her lack of graphic novels, "I really didn't know enough about them. I am thinking about buying them now, with our next funds allocation, but I need more information.” The survey may have prompted her interest in graphic novels although she did not explicitly say this. The research project Web site was shared with respondents, and it has links to more information on graphic novels, both online and in print. This librarian may subsequently find out what she needs to know and start a collection.

\section{Location of Library Compared to Presence of a Graphic Novel Collection}

Correlations between selected characteristics of the libraries and the presence of graphic novel collections were determined using cross-tabulations between variables. Even with the good survey response, it must be recognised that cell counts did not always meet the criteria for valid results. The cross-tabulations were significantly 
correlated with a Pearson Chi-square test probability of less than 0.05 , but some had cells with a count of less than five.

The comparison between the location of a library ${ }^{*}$ and the presence of a graphic novel collection is shown in Figure 3.

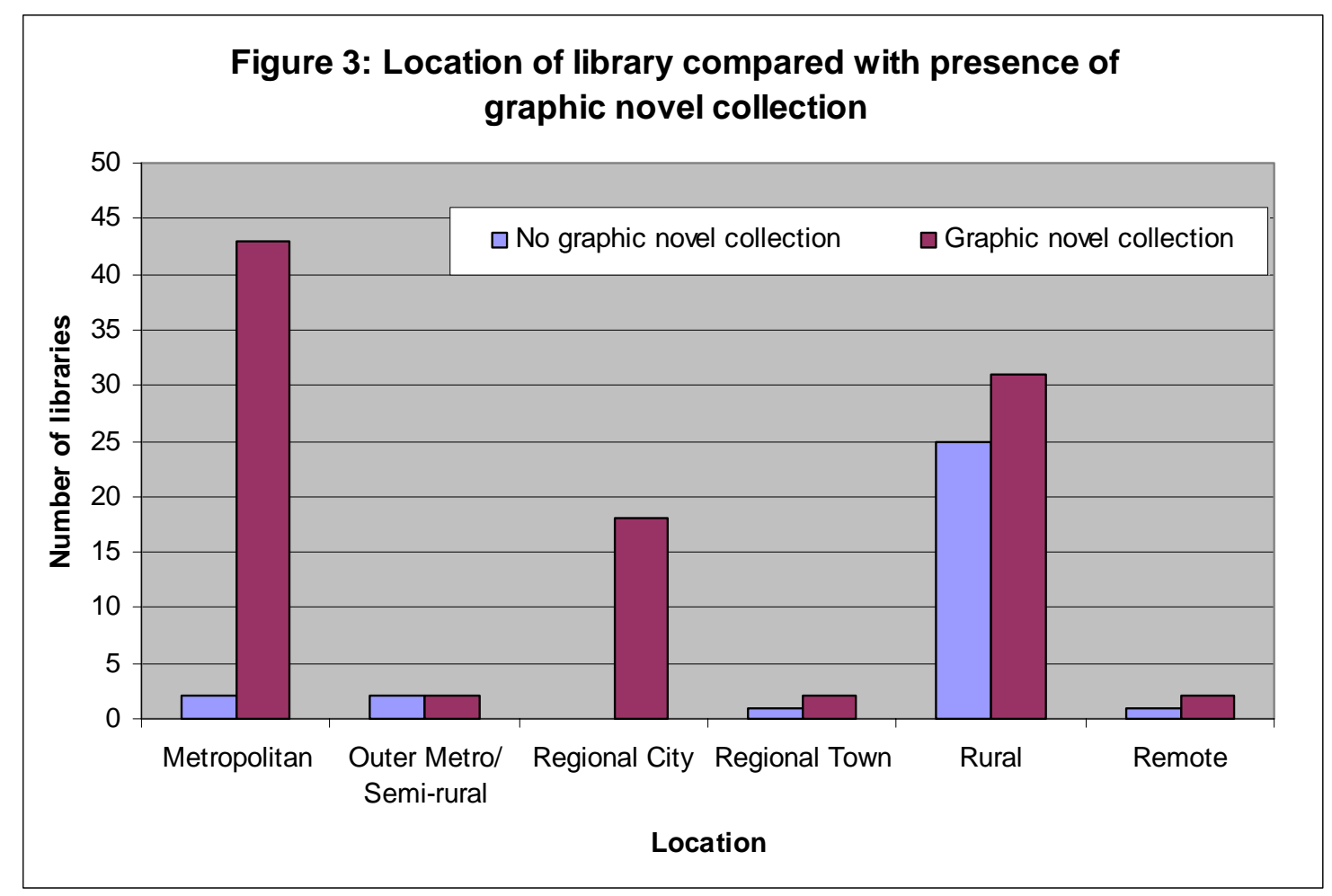

The smaller groupings were combined (metropolitan with outer metropolitan / semirural \& regional city; and regional town with rural \& remote) to remove groupings with a count less than five and make the variations clearer. The combined locations of libraries compared with presence of graphic novel collections are shown in Figure 4.

\footnotetext{
* Location of library was determined by the respondent rather than the researcher looking at populations of areas and assigning a location.
} 


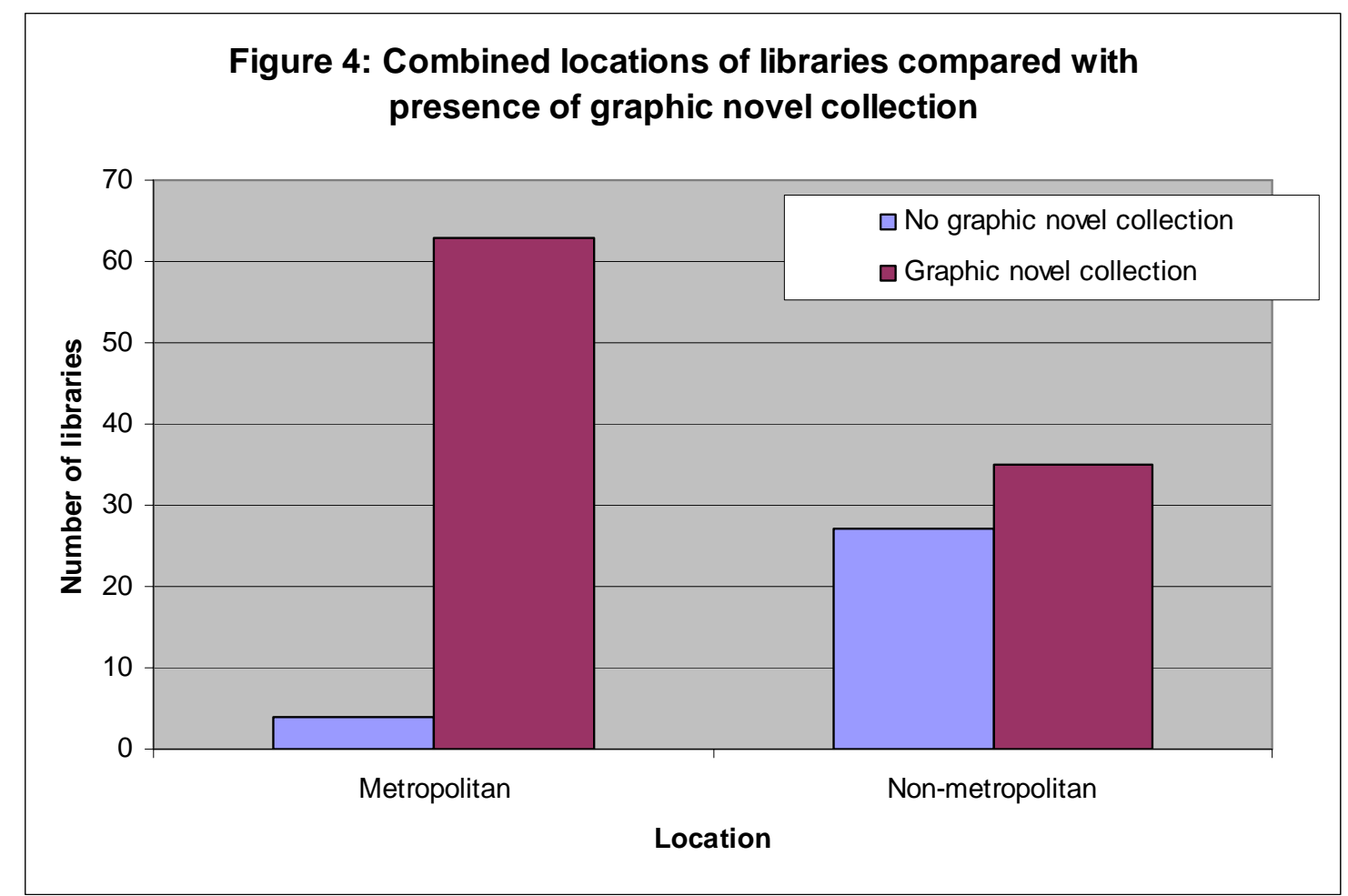

The results indicate that a library in a metropolitan area is more likely to have a graphic novel collection than not, and in a non-metropolitan area there is an approximately even split between having and not having a graphic novel collection.

The comparison between the state or territory of a library and the presence of graphic novel collections is shown in Table 2 and Figure 5.

Table 2: State or Territory of Libraries

\begin{tabular}{l|r|r|r|r} 
& $\begin{array}{c}\text { No graphic novel } \\
\text { collection }\end{array}$ & $\begin{array}{c}\text { Graphic novel } \\
\text { collection }\end{array}$ & Total & $\begin{array}{c}\text { Percentage of } \\
\text { libraries with } \\
\text { graphic novels }\end{array}$ \\
\hline ACT & 0 & 4 & 4 & 100.00 \\
\hline NSW & 3 & 23 & 26 & 88.46 \\
\hline TAS & 1 & 6 & 7 & 85.71 \\
\hline QLD & 4 & 19 & 23 & 82.61 \\
\hline SA & 5 & 18 & 23 & 78.26 \\
\hline VIC & 4 & 14 & 18 & 77.78 \\
\hline NT & 3 & 4 & 7 & 57.14 \\
\hline WA & 11 & 10 & 21 & 47.62 \\
\hline Total & 31 & 98 & 129 & 75.97
\end{tabular}




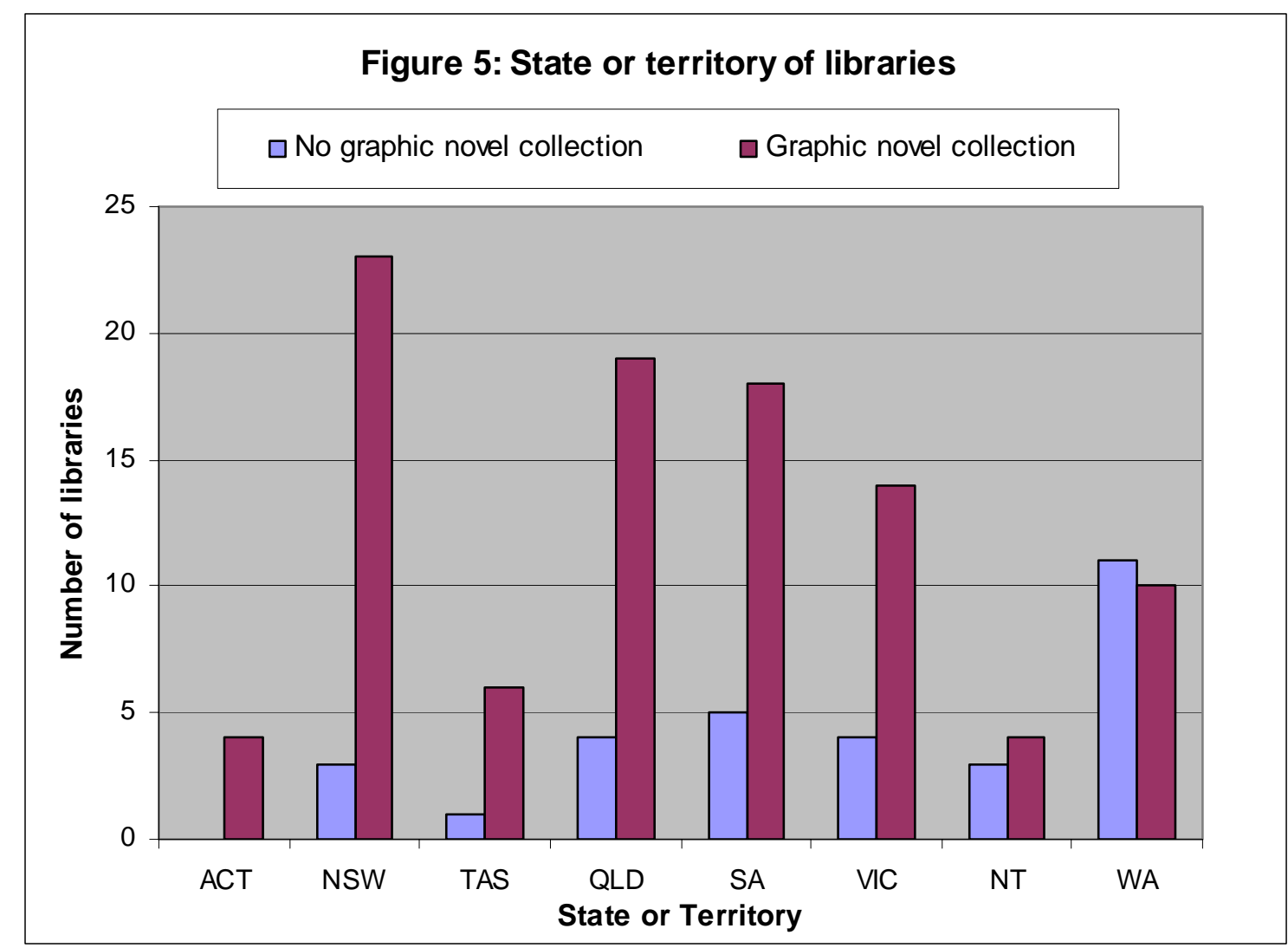

The Western Australian (WA) respondents had the lowest percentage of libraries with graphic novel collections at $47.62 \%(n=10)$. All Australian Capital Territory (ACT) respondents had graphic novel collections. Those from New South Wales (NSW) had the second highest percentage of libraries with graphic novel collections at $88.46 \%$ $(n=23)$. A number of reasons could have contributed to these disparities.

Some NSW libraries in the sample did not have a graphic novel collection and passed the questionnaire onto another library in their system that did (although not all libraries that did this were from NSW).

The Library Council of New South Wales distributes "Library Development Grants for projects that support the development of better public library services for the people of New South Wales" (State Library of New South Wales \& Library Council of New South Wales, 2005, p. 5) A number of NSW respondents mentioned that their collections were started with one of these grants. A couple of years ago, Holroyd City Council Library received one of these grants to start their graphic novel collection (Library Council of New South Wales, 2005, p. 73).

The WA respondents were overwhelmingly located in rural areas $(61.90 \%, \mathrm{n}=13)$ compared to only $30.77 \%(n=8)$ of NSW respondents located in rural areas. As noted, a library located in a metropolitan area is more likely to have a graphic novel collection. At the same time, a similar number of Queensland (Qld) respondents were located in non-metropolitan areas $(65.22 \%, n=15)$, and most of their libraries had graphic novel collections (82.61\%, $\mathrm{n}=19)$.

\section{Selection Criteria and Collection Development Policies}

One question in the survey asked about selection criteria. With the trend for libraries being to produce written collection development policies (Evans \& Saponaro, 2005, p. 
51), selection criteria have become explicit rather than being implicit knowledge that the librarian carries in her head (Jacob, 1990, p. 166). Sixty percent of libraries that answered this question said graphic novels were not included in their collection development policy or that the policy was currently being updated. Another worrying trend was that $20 \%$ of libraries that answered this question said they did not use selection criteria. It could be that the criteria are not articulated rather than that selection criteria are not being used. Two examples of responses to this question were

"Not really, [we] look more for those with less gratuitous violence. Usually fiction, not non-fiction."

"No, just what's popular. What we think people will read."

Both of these respondents contradict their initial "no" and do use selection criteria (answers like this were not included in the 20\%). Perhaps respondents do not often think of what the criteria they use actually are.

On a more positive note, some answers to this question were very enlightening, for example,

C/YA: age appropriateness, mixture of male and female appeal, mix of manga ${ }^{*}$ and non-manga, mix of genres, high appeal, adequate physical sturdiness.”

The respondent was the children's and youth co-ordinator who selects only children's and young adult (C/YA) graphic novels. Adult graphic novels are selected by a different librarian.

\section{Collection Development or Censorship?}

Occasionally graphic novel collections in libraries are subjected to challenges, mostly for individual titles that a library user finds objectionable. Some people (usually those with little knowledge of the format) object to all graphic novels because of particular titles or even just one image in a title (Goldsmith, 2005). In the past, comics and graphic novels have been thought of as "just for kids" (Versaci, 2001, p. 63). This is not the case, and the visual nature of graphic novels makes some titles aimed at a more mature audience more easily accessible than text items and thus seen as “inappropriate” (Miller, 2005, p. 59). In discussing adult manga in Japan, Fred Patten, long-time writer on manga, anime, and Japanese culture, states, "Practically every adult [Japanese] comic of any length will involve sexual relationships at some point, usually graphically depicted though not to the extent of being X-rated” (2004, p. 236).

It could happen that a child or teenage library user could read or borrow an adult graphic novel and subsequently have his or her parent become upset. (It would be hoped that the particular item was not actually shelved in a junior or YA section). If this happens in a public library, the usual response is that it is the parent's responsibility to supervise what his or her children read and borrow (National Coalition Against Censorship, American Library Association, \& Comic Book Legal Defense Fund, 2006, p. 6). Extreme cases of challenges, where parents ask for titles to be removed from the library (Goldsmith, 2005; Miller, 2005), seem to be more common in U.S. libraries than in those in Australia. In some unfortunate U.S. cases,

\footnotetext{
* Manga are Japanese comics. Many are translated into English and published in the U.S.
} 
this has been done although usually by a local government official rather than a librarian (Gonzalez, 2006).

One comment from a survey respondent shows concern that challenges are alive and well in Australian libraries. In answer to a question regarding how the library's collection is promoted, the reply was that such promotion "may draw attention of some council and community members to a collection they do not approve of, and attempt to ban purchase of all graphic novels." Such a situation could lead to censorship through non-selection in a library. This particular respondent is aware of her professional responsibilities as a children's and youth librarian and ended her comment on a more positive note, "graphic novels [are] a valid and useful part of a library collection." Another factor in the library's low-key promotion is that they "do not have the budget to meet the demand this [promotion] would create."

To complicate matters, Ranma 1/2 (1988) by Rumiko Takahashi is an example of a graphic novel aimed at teenagers that has some nudity. The "nudity is sometimes employed for comedic effect, but never for salacious purposes” (Lyga \& Lyga, 2004, p. 77), but parents could still find it objectionable. Lyga and Lyga discuss graphic novels suitable for school libraries and "recommend the book for its insight into Japanese culture, from the architecture, to school uniforms, to the food, to the ubiquitous bathing rituals” (p. 77).

On a less positive note, another respondent said in answer to the question about selection criteria, "Not overly 'bloody' —no manga." It is assumed bloody equates to extreme violence, which is present in some manga, although not those aimed at children and teenagers. It is unfortunate that the person responsible for selection of graphic novels does not realise the full spectrum of manga available. Related to this is the observation from one respondent, "There is more tolerance for violence than for sex or nudity."

\section{Other selected findings}

One respondent from a small Queensland rural library that is part of the State Library of Queensland's (SLQ) Country Lending Scheme said, "I request graphic novels on my exchange sheet and SLQ sends what they have available.” This is similar to the situation in small rural libraries in Western Australia (WA). If the library officer knows about graphic novels, she can ask for them. On the flip side, library officers who do not know about them will not have a collection. A library officer from a small WA rural library said, "I had never heard of graphic novels before reading this survey." She also added, "The people in town, especially children, have poor literacy skills and don't use the library very much.” Perhaps graphic novels would be just the thing to increase library use.

After inputting three surveys from the Northern Territory, the researcher noticed an unexpected difference among them. As determined from survey responses, Northern Territory public libraries have centralised acquisitions, purchasing, cataloguing, and processing for some or all of their materials. The first library has a well used graphic novel collection with graphic novels being borrowed as soon as they are displayed. Word of mouth among borrowers means graphic novels are often requested when still on loan. The other two libraries do not make a special effort to collect graphic novels, and "there is little use of resources by [the] relevant age group." Of the few teenagers who do come in, they don't use the few graphic novels the libraries have. As the 
Northern Territory Library (2006) states, the user populations have had a large impact on the different libraries' collections.

In the Northern Territory, a large segment of the population is of indigenous origin (ABS, 2001). There is a "preference by indigenous library users for visual materials" (Senior, 2006). Graphic novels are one example of visual materials, but the lack of Australian graphic novels and thus of those with indigenous characters may lead to their being of little interest to indigenous people. The oral culture of indigenous people (Senior, 2006) may also contribute to such visual materials as DVDs or electronic resources being more popular than graphic novels.

United States librarian Robin Brenner has said, “it may seem there's no demand for graphic novels, but, once they appear on the shelves, the audience will come out of the woodwork and demand more” (Welsh, 2006, p. 85). As the above attests, this is not always the case.

Another U.S. librarian, Michelle Gorman, has said, "Word of mouth is your best form of publicity" (2003, p. 36). A number of the survey respondents said their collection needs no promotion because word of mouth does it all. This seems to have been the case with one very new collection: "Just putting them on the shelf resulted in half the JCO [children's graphic novel] collection going out in half an hour.”

Many collections have only been started in the last year, for example, at the Whitehorse Manningham Regional Library as reported in the Whitehorse Gazette in October 2005 ("Making News Around Australia," 2005). This suggests that a number of respondents are still building their collections. An exception to the above was the metropolitan NSW library that "purchased a lot [of graphic novels] and then backed off to only fifty per year." This library also started with a separate section for their collection and then changed to interfiling graphic novels within fiction. Most libraries interfile their collection when it is small and as it grows the collection is separated (Goldsmith, 2005; Miller, 2005).

\section{Conclusion}

Graphic novel collections in Australian public libraries and teenagers' use of graphic novels are being investigated using three different research methods. A postal survey of public libraries in Australia was conducted to determine whether public libraries have graphic novel collections and how these collections are selected, acquired, catalogued, housed, and promoted. Focus groups with teenagers will be conducted to uncover what teenagers think of graphic novels and whether they read them. Public librarians who have graphic novel collections in their library will be interviewed to determine their thoughts on their collections and the format in general.

The three research methods were chosen to ensure different population groups will be studied in different ways. This enables triangulation that will provide a rich and diverse picture of graphic novel use in Australia.

Analysis of the survey results is ongoing, and some of these initial findings may be reassessed. The analysis so far has shown differences resulting from the location of public libraries, both in terms of metropolitan or non-metropolitan area and state or territory, and their graphic novel collections or lack of graphic novels. Although a random sample of public libraries was aimed for, the problems encountered with the sample indicate that care should be taken in generalizing the results to all public libraries in Australia. 
The focus groups with teenagers and interviews with librarians are yet to be completed but will hopefully proceed without problems and will contribute to the picture being developed more fully. 


\section{Reference List}

ABS. (2001). Indigenous population: Proportion of total ATSIC region population. Retrieved 5 Oct 2006 from http://abs.gov.au/websitedbs/d3310116.nsf/cd7fca67e05fa605ca256e6a00171f 24/20c901e2efec4105ca256ef600219af2!OpenDocument

ABS. (2005). Public libraries: 2003-04 (No. 8561.0). Canberra: Australian Bureau of Statistics.

Agosto, D. E., \& Hughes-Hassell, S. (2006). Toward a model of the everyday life information needs of urban teenagers, part 1: Theoretical model. Journal of the American Society for Information Science and Technology, 57(10), 1394 1403.

Albright, J., \& Walsh, C. (2003). Jamming visual culture. Literacy Learning: The Middle Years, 11(2), 15-21.

Baker, L., Dreher, M. J., \& Guthrie, J. T. (2000). Why teachers should promote reading engagement. In L. Baker, M. J. Dreher \& J. T. Guthrie (Eds.), Engaging young readers: Promoting achievement and motivation (pp. 1-16). New York: Guilford Press.

Berg, B. L. (2004). Qualitative research methods for the social sciences (5th ed.). Boston, MA: Allyn and Bacon.

Bouma, G. D., \& Ling, R. (2004). The research process (5th ed.). Oxford: Oxford University Press.

Buckland, M. K. (2003). Five grand challenges for library research. Library Trends, 51(4), 675-686.

Bunbury, R. M. (Ed.). (1995). Children's choice: Reading at home or at school. Geelong, Vic.: Deakin University Press.

Bundy, A. L., \& Bundy, J. (Eds.). (2006). Directory of Australian public libraries (7th ed.). Adelaide, SA: Auslib Press.

Campher, G., Cohen, J., DeBrady, P., Gold, L., Jones, L., Mason, B., et al. (1996). Taking stock/making change: Focusing on student voices at AMY Northwest. Philadelphia, Pa.: Research for Action.

Chartered Institute of Library and Information Professionals. (2005, 10 May). Arts Council consultation on children's literature. Retrieved 12 Jul 2005 from http://www.cilip.org.uk/professionalguidance/lobbying/consultations2003/chil drenslit.htm

Crawford, P. C. (2003). Graphic novels 101: Selecting and using graphic novels to promote literacy for children and young adults: A resource guide for school librarians and educators. Salt Lake City, UT: Hi Willow.

Creswell, J. W. (2002). Educational research: Planning, conducting, and evaluating quantitative and qualitative research. Upper Saddle River, NJ: Merrill.

Dillman, D. A. (2000). Mail and Internet surveys: The tailored design method (2nd ed.). New York: Wiley.

Dodds, I., \& Cheesman, R. (2003). Reading Remix: Consulting young people in South-East London. In I. Dodds (Ed.), Reading remixed: New approaches to library services for teenagers (pp. 14-17). London: Youth Libraries Group.

Doyle, J. K. (2004, 25 May). Introduction to interviewing techniques. Retrieved 13 May 2005 from http://www.wpi.edu/Academics/Depts/IGSD/IQPHbook/ch11.html

Druin, A. (2005). What children can teach us: Developing digital libraries for children with children. Library Quarterly, 75(1), 20-41. 
Evans, G. E., \& Saponaro, M. Z. (2005). Developing library and information center collections (5th ed.). Westport, CT: Libraries Unlimited.

Frey, N., \& Fisher, D. (2004). Using graphic novels, anime, and the Internet in an urban high school. English Journal, 93(3), 19-25.

Goldsmith, F. (2005). Graphic novels now: Building, managing, and marketing a dynamic collection. Chicago: American Library Association.

Gonzalez, M. (2006, 25 Apr). Postmus urged to keep comic book in libraries. Daily Press. Retrieved 12 Sep 2006 from http://www.vvdailypress.com/2006/114597098999319.html

Gorman, G. E., \& Clayton, P. (2005). Qualitative research for the information professional: A practical handbook (2nd ed.). London: Facet Publishing.

Gorman, M. (2003). Getting graphic! Using graphic novels to promote literacy with preteens and teens. Worthington: Linworth.

Gravett, P. (2005). Graphic novels: Stories to change your life. London: Aurum Press.

Hale, J. A. (1994). Developing lifelong readers: An in-depth study of children's responses to literature. $\mathrm{PhD}$ Thesis, Mississippi State University, Starkville.

Hawke, B., \& Jenks, F. (2005). On the move: Mobile library services in New Zealand. APLIS: Australian Public Library and Information Services, 18(3), 93-105.

Haynes, A. (2004). Bridging the gulf: Mixed methods and library service evaluation. Australian Library Journal, 53(3), 285-306.

Hayslett, M. M., \& Wildemuth, B. M. (2004). Pixels or pencils? The relative effectiveness of web-based versus paper surveys. Library \& Information Science Research, 26(1), 73-93.

Jacob, M. (1990). Get it in writing: A collection development plan for the Skokie Public Library. Library Journal, 115(14), 166-169.

Kan, K. L. (2003). Getting graphic at the school library. Library Media Connection, 21(7), 14-19.

Krashen, S. D. (2004). The power of reading: Insights from the research (2nd ed.). Westport, Conn.: Libraries Unlimited.

Krueger, R. A., \& Casey, M. A. (2000). Focus groups: A practical guide for applied research (3rd ed.). Thousand Oaks, CA: Sage Publications.

Library Council of New South Wales. (2005). Annual report 2004/05. Sydney, NSW: State Library of New South Wales.

Loubeau, P. R. (2000). Exploration of the barriers to bicycle helmet use among 12 and 13 year old children. Accident Analysis \& Prevention, 32(1), 111-115.

Love, K., \& Hamston, J. (2003). Teenage boys’ leisure reading dispositions: Juggling male youth culture and family cultural capital. Educational Review, 55(2), 161-177.

Lyga, A. A. W., \& Lyga, B. (2004). Graphic novels in your media center: A definitive guide. Westport, CT: Libraries Unlimited.

Macauley, P. (2006). Why do you need a PhD? Incite, 27(3), 22-23.

Mahoney, B. (2006). Graphic novels in the classroom. Viewpoint: On Books for Young Adults, 14(1), 2-4.

Making news around Australia. (2005). Incite, 26(10), 29.

Mangione, T. W. (1998). Mail surveys. In L. Bickman \& D. J. Rog (Eds.), Handbook of applied social research methods (pp. 399-427). Thousand Oaks, CA: Sage.

Miller, S. (2005). Developing and promoting graphic novel collections. New York: Neal-Schuman Publishers. 
National Coalition Against Censorship, American Library Association \& Comic Book Legal Defense Fund. (2006). Graphic novels: Suggestions for librarians. New York: NCAC.

National Library of Australia. (2005). Australian Libraries Gateway. Retrieved 29 Sep 2005 from http://www.nla.gov.au/libraries

Northern Territory Library. (2006, 25 Aug). Libraries and knowledge centres: The facts. Retrieved 8 Sep 2006 from http://www.dcdsca.nt.gov.au/dcdsca/intranet.nsf/Pages/ntl_lkc

O’English, L., Matthews, J. G., \& Lindsay, E. B. (2006). Graphic novels in academic libraries: From Maus to Manga and beyond. The Journal of Academic Librarianship, 32(2), 173-182.

Page, S. (2005). Australian young adult keen readers: Choices they make, and creators' views regarding the young adult market. PhD Thesis, University of Canberra, Canberra.

Patten, F. W. (2004). Watching anime, reading manga: 25 years of essays and reviews. Berkeley, CA: Stone Bridge Press.

Powell, R. R., \& Connaway, L. S. (2004). Basic research methods for librarians (4th ed.). Westport, CT: Libraries Unlimited.

Raiteri, S. (2002). Graphic novels. Library Journal, 127(14), 148.

Schonlau, M., Fricker, R. D., \& Elliott, M. N. (2002). Conducting research surveys via e-mail and the web. Santa Monica, CA: RAND Corporation.

Schwartz, A., \& Rubinstein-Avila, E. (2006). Understanding the manga hype: Uncovering the multimodality of comic-book literacies. Journal of Adolescent \& Adult Literacy, 50(1), 40-49.

Senior, D. (2006, 19 Sep). Akaltye Antheme: Local knowledge collection. Paper presented at the Library Stars: The Best of the Best, Perth, WA. Retrieved 17 Nov 2006 from http://alia.org.au/governance/committees/public.libraries/presentations/alice\% 20springs.doc

Shenton, A., \& Dixon, P. (2004). Issues arising from youngsters' information-seeking behaviour. Library \& Information Science Research, 26(2), 177-200.

Sieber, J. E. (1992). Planning ethically responsible research: A guide for students and internal review boards. Newbury Park, CA: Sage.

Stake, R. E. (2000). Case studies. In N. K. Denzin \& Y. S. Lincoln (Eds.), Handbook of qualitative research (2nd ed., pp. 435-454). Thousand Oaks, CA: Sage.

State Library of New South Wales \& Library Council of New South Wales. (2005). Library development grant guidelines: 2006/07. Sydney, NSW: Library Council of NSW.

Sullivan, E. T. (2002). Reaching reluctant young adult readers: A handbook for librarians and teachers. Lanham, MD: Scarecrow Press.

Takahashi, R. (1988). Ranma 1/2. San Francisco: Viz.

Thomson, J. (1987). Understanding teenagers' reading: Reading processes and the teaching of literature. Norwood, SA: AATE.

Vaillancourt, R. J. (2000). Bare bones young adult services: Tips for public library generalists. Chicago: American Library Association.

Versaci, R. (2001). How comic books can change the way our students see literature: One teacher's perspective. English Journal, 91(2), 61-67.

Walter, V. A. (1995). Output measures and more: Planning and evaluating public library services for young adults. Chicago: American Library Association. 
Welsh, D. (2006). The Flipped Interview with Robin Brenner. Comic World News. Retrieved 6 Sep 2006 from http://www.comicworldnews.com/cgibin/index.cgi?column=flipped\&page $=85$

Widdows, R., Hensler, T. A., \& Wyncott, M. H. (1991). The focus group interview: A method for assessing users' evaluation of library service. College \& Research Libraries, 52(4), 352-359.

Wilkinson, S. (1998). Focus group methodology: A review. International Journal of Social Research Methodology, 1(3), 181-203.

Wilkinson, S. (2004). Focus group research. In D. Silverman (Ed.), Qualitative research: Theory, method and practice (2nd ed., pp. 177-199). London: Sage.

Williamson, K., Bannister, M., Makin, L., Johanson, G., Schauder, D., \& Sullivan, J. (2006). Wanting it now: Baby boomers and the library of the future. Australian Library Journal, 55(1), 54-72.

Wood-Charlesworth, L., \& Rodwell, M. K. (1997). Focus groups with children: A resource for sexual abuse prevention program evaluation. Child Abuse \& Neglect, 21(12), 1205-1216. 